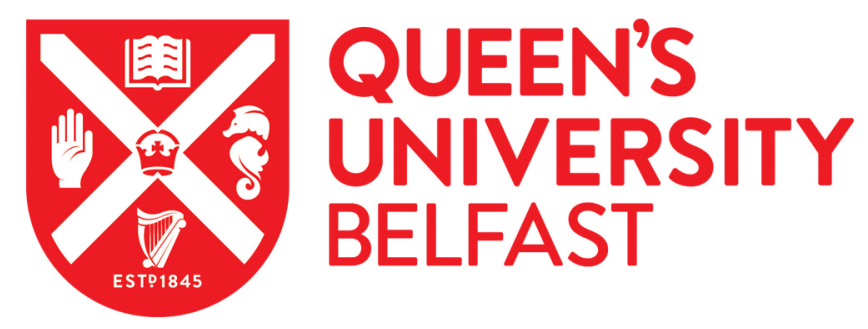

\title{
The case of the Irish National Contact Point for the OECD Guidelines for Multinational Enterprises: Challenges and opportunities for the business and human rights landscape in Ireland
}

Hackett, C., O'Kelly, C., \& Patton, C. (2019). The case of the Irish National Contact Point for the OECD Guidelines for Multinational Enterprises: Challenges and opportunities for the business and human rights landscape in Ireland. Irish Jurist, 61(1). http://www.irishjurist.com/index.htm

Published in:

Irish Jurist

Document Version:

Peer reviewed version

Queen's University Belfast - Research Portal:

Link to publication record in Queen's University Belfast Research Portal

Publisher rights

(c) 2018 The Irish Jurist

This work is made available online in accordance with the publisher's policies. Please refer to any applicable terms of use of the publisher.

\section{General rights}

Copyright for the publications made accessible via the Queen's University Belfast Research Portal is retained by the author(s) and / or other copyright owners and it is a condition of accessing these publications that users recognise and abide by the legal requirements associated with these rights.

Take down policy

The Research Portal is Queen's institutional repository that provides access to Queen's research output. Every effort has been made to ensure that content in the Research Portal does not infringe any person's rights, or applicable UK laws. If you discover content in the

Research Portal that you believe breaches copyright or violates any law, please contact openaccess@qub.ac.uk. 


\title{
The case of the Irish National Contact Point for the OECD Guidelines for Multinational Enterprises: Challenges and opportunities for the business and human rights landscape in Ireland
}

\author{
Ciara Hackett, Ciaran O’Kelly and Clare Patton* \\ (Queen's University Belfast)
}

\begin{abstract}
The "Zero Draft" Treaty on Business and Human Rights was published in July 2018. Similar to earlier manifestations of treaty discussions, this draft places the right of and access to remedy at the centre of negotiations. In this way, this treaty follows an analogous pathway to the United Nations Guiding Principles on Business and Human Rights (UNGPs); namely, that victims of human rights impacts should have access to an effective remedy. The draft does not however, discuss in detail how remedy might be enforced.
\end{abstract}

To understand how remedy enforcement may work in practice, the UNGPs offer some guidance. They point to the National Contact Point (NCP). NCPs are a product of the OECD Guidelines for Multinational Enterprises and provide victims of human rights violations with a platform to lodge a complaint against a corporation. The NCP's role is to investigate this complaint and where appropriate, mediate on a solution, and act as an enforcer. This is not the NCP's only role, but it is the aspect of its activities on which the UNGPs focus. The global experience of the NCP has been varied with promotion of the NCP's activities differing depending on the nation state. Despite this, the UNGPs have continued to endorse the NCPs as both a potential route to effective remedy and as an enforcement mechanism.

In this article, we look at the legal framework on business and human rights in Ireland. We note that whereas the proposed draft treaty does not explicitly reference NCPs in its current form, the language contained within mirrors that of the UNGPS and the OECD (to a lesser extent) suggesting a role for the NCP moving forward. Therefore, we propose a list of recommendations to enhance the existing NCP framework, thus ensuring that, should the proposed treaty be developed (in line with the current draft) Ireland can fulfill its obligations and offer clear guidance for victims needing to engage the NCP framework.

Key Words: Business and Human Rights, UNGPS, OECD, National Contact Points 


\section{Introduction}

The National Contact Point (NCP) is, amongst other things, the implementation and enforcement mechanism of the OECD Guidelines for Multinational Enterprises (OECD Guidelines). ${ }^{1}$ The OECD Guidelines are non-binding, valuable standards for responsible business conduct within the global context. Although a respected contribution to the business and human rights discourse, the Guidelines only apply to a small and relatively homogenous group of countries. However, the United Nations Guiding Principles on Business and Human Rights (UNGPs) make the implicit suggestion that the NCP mandate is expanded to incorporate the UNGPs. This builds on the revised OECD Guidelines (revised in 2011), which included a section on human rights, in recognition of the UNGPs and their relevance and importance to the business and human rights landscape. The UNGPs are the most recent attempt to negotiate the relationship between state, business and remedy. ${ }^{2}$ These guiding principles rest on three core pillars: (1) the state duty to protect human rights; (2) the corporate duty to respect human rights; and, (3) the right to a remedy where a human rights impact has occurred. In addition to outlining the types of remedy available to victims of human rights impacts, pillar 3 also identifies some ways in which remedy can be enforced. One of the proposed enforcement mechanisms is via the NCP. ${ }^{3}$

\footnotetext{
*Lecturers in School of Law at Queen's University Belfast. Contact Author: Ciara Hackett (c.hackett@qub.ac.uk)
}

Thank you to the anonymous review which forced us to reflect and reimagine this piece for our audience. Their input enhanced the quality of the piece. Mistakes and errors remain our own.

${ }^{1}$ OECD Guidelines for Multinational Enterprises, (2011) Available at <

http://mneguidelines.oecd.org/database/> [Accessed August 20, 2018]. For a useful analysis of the legal role of the NCP, see, Scott Robinson, 'International Obligations, State responsibility and judicial review under the OECD Guidelines for Multinational Enterprises Regime' (2014) 30 (78) Utrecht Journal of International and European Law 68

2 United Nations Guiding Principles on Business and Human Rights (UNGPs), Available at < https://www.ohchr.org/Documents/Publications/GuidingPrinciplesBusinessHR EN.pdf> [Accessed August 2, 2018]; Florian Wettstein, 'Normativity, Ethics and the UN Guiding Principles on Business and Human Rights: A critical assessment' (2015) 14 (2) Journal of Human Rights 162 - 182

${ }^{3}$ Principle 25, UNGPs, Additional Commentary, p. 27. Available at < https://www.ohchr.org/Documents/Publications/GuidingPrinciplesBusinessHR EN.pdf> [Accessed August 2, 2018] 
The importance of the NCP therefore lies in the weight and respect placed on it by both the OECD Guidelines and the UNGPs. It is viewed as a route by which victims may receive a remedy for the human rights impacts that they have experienced. ${ }^{4}$ Therefore the effectiveness and efficiency of the NCP is paramount. However, the NCP experience is mixed. Because the NCP is within the remit, design, and in some cases, control, of the state, there are variations on how the NCP is experienced worldwide. The UNGPS, through the language of their additional commentary, suppose a homogenous experience with the NCP in the countries where it has been operational. This additional commentary makes no reference to country disparities, or to the position of those countries that are neither members, nor even adhering countries of the OECD Guidelines (and by extension National Contact Points). In practice, the experience of the NCPs in member and adhering countries has differed greatly. ${ }^{5}$ For example, in 2017, 18 (out of $48-38 \%$ ) NCPs received specific instance submissions. ${ }^{6}$ Many countries (including Ireland) have not received a submission in a number of years. Ireland has had two reported instances - with the most recent, and, as yet, unresolved, originating in $2011 .{ }^{7}$

\footnotetext{
${ }^{4}$ Note, the language of the UNGPs references 'impacts' over 'violations' - we have kept to the language of the UNGPs throughout this piece.

${ }^{5}$ Ciara Hackett, Development in an era of Capital Control (Palgrave Macmillan 2017); For the OECD Guidelines and the NCPs generally, see Jernej Letnar Cernic, Corporate responsibility for human rights: A critical analysis of the OECD guidelines for multinational enterprises. (2008) 4 Hanse Law Review 71 ${ }^{6}$ Annual Report on the OECD Guidelines for Multi National Enterprises 2017, Available at < http://mneguidelines.oecd.org/2017-Annual-Report-MNE-Guidelines-EN.pdf> [Accessed August 20, 2018] p. 8

${ }^{7}$ Specific Instance notified by an NGO regarding the activities of a multinational enterprise in the Palestinian Authority, (2011) Available < http://mneguidelines.oecd.org/database/instances/ie0002.htm> [Accessed August 1, 2018]; Specific instance notified by Pobal Chill Chomain, a community group in North Mayo, Ireland and two NGOs regarding the activities of Shell Exploration and Production Ireland Limited (SEPIL) et al. operating in Ireland. (2008), Available <

http://mneguidelines.oecd.org/database/instances/ie0001.htm> [Accessed July 23, 2018]

Contrast this with the United Kingdom where there have been 48 reported instances (United Kingdom Specific Instances <

http://mneguidelines.oecd.org/database/searchresults/?q=(NCP:(United\%20Kingdom)> [Accessed July 1, 2018])>; the United States (48 reported instances) (United States Specific Instances < http://mneguidelines.oecd.org/database/searchresults/?q=(NCP:(United\%20States) $>$ [Accessed July 1 , 2018])>; >; Brazil, an adherent country to the OECD (24 reported instances) (Brazil Specific Instances < http://mneguidelines.oecd.org/database/searchresults/?q=(NCP:(Brazil) [Accessed July 1, 2018])>;)>, the Netherlands (29 reported instances) (Netherlands Specific Instances < http://mneguidelines.oecd.org/database/searchresults/?q=(NCP:(Netherlands) [Accessed July 1, 2018])>;)>); Israel which also has two reported instances (Israel Specific Instances < http://mneguidelines.oecd.org/database/searchresults/?q=(NCP:(Israel))> [Accessed July 1, 2018])>;) and tiny Latvia with one reported instance (Latvia Specific Instances, < http://mneguidelines.oecd.org/database/searchresults/?q $=($ NCP:(Latvia) $)>[$ Accessed July 1, 2018])>)
} 
Recently, another challenge has emerged. Discussions are ongoing on a draft treaty on business and human rights. ${ }^{8}$ The most recent draft - referred to as the zero draft recognises the centrality of and access to remedy. The draft seems to place a greater weight on domestic routes to remedy. Whereas the NCPs are not expressly referenced, the language in the draft - and article 15 in particular - supposes that enforcement similar to that suggested in the additional commentary of the UNGPs can be predicted. ${ }^{9}$ This suggests a role for the state based NCP (albeit not necessarily in its current form) in future. The challenge for the NCP is to understand and manage the expectations of the law, guidelines and standards whilst maintaining the integrity of the entity. With this in mind, in this article we explore how the existing NCP structure can be enhanced. We do this by focusing on the Irish NCP and how, by returning to the language of the OECD Guidelines, and specifically the core criteria for functional equivalence, ${ }^{10}$ that the NCP can become more effective and potentially move beyond the narrow role ascribed to it within the UNGPs. We do this in the context of the Irish National Action Plan; its purpose is to give effect to the UNGPs in Ireland. Given the role potentially ascribed to the NCPs in relation to remedy and enforcement of remedy within the UNGPs ${ }^{11}$ we believe that it is important to reflect on the implications of the National Action Plan on the NCP and the wider protection and respect of business and human rights in Ireland. The first section of this piece provides an overview of the complex legal framework that establishes the foundations for the business and human rights infrastructure. Whereas this is not exclusive, it touches on the areas of law and practice which may influence or be influenced by the actions of the NCP. Section II addresses the Irish experience of the NCP to date, and the final section proposes a

\footnotetext{
8 Larry Catá Backer, 'Principled Pragmatism in the elaboration of a comprehensive treaty on Business and Human Rights. In, Building a Treaty on Business and Human Rights: Context and Contours, pp. 105-130 (Cambridge, Cambridge University Press 2017); David Bilchitz, 'The necessity for a business and human rights treaty' (2016 1(2) Business and Human Rights Journal 203-227

${ }^{9}$ Art. 15 (1) Legally binding instrument to regulate, in international human rights law, the activities of transnational corporations and other business enterprises (16.07.2018) Available at < https://www.business-humanrights.org/sites/default/files/documents/DraftLBI.pdf> [Accessed August 27, 2018]

${ }^{10}$ The procedural guidance of the OECD Guidelines outlines the role and objectives of the NCP. It notes that the NCP must operate in accordance with the core criteria of visibility, accessibility, transparency and accountability in ensure functional equivalence. This means that whereas governments have the flexibility to organise NCPs as they wish, they must ensure that the operation of the NCP reflects these core criteria to ensure some level of uniformity.

11 We refer here to the additional commentary on principle 25 which suggests that state based grievance mechanisms may avail of the National Contact Points under the OECD Guidelines. It continues by noting that state based judicial and non-judicial mechanisms should form the foundation of a wider system of remedy. We believe that this is interesting in that it potentially imposes another duty (via the UNGPs) on an initiative established under a different set of guidelines (OECD Guidelines)
} 
series of recommendations to augment the potential of the Irish NCP in securing a route to remedy for those who have experienced a human rights impact.

\section{I: The Legal Landscape of Business and Human Rights}

The landscape of business and human rights covers a myriad of laws at domestic, supranational (in the case of the EU) and international levels. ${ }^{12}$ Whereas there have been a spate of recent state-level decisions which touch on the themes of remedy and access, ${ }^{13}$ we are focused more on the laws and standards that have emerged from primarily the international discourse, and how these have been understood and embedded within the Irish experience. We focus on the right to remedy, the access to that remedy and enforcement mechanisms. ${ }^{14}$

\section{A. International Law}

Currently business and human rights is primarily considered under soft law initiatives. Although these do not have the same legal effects as a proposed treaty, they still can and do have a significant influence on how states and businesses protect and respect human rights in the course of their operations. Initially, the OECD Guidelines mapped the landscape in this area. However, the most prolific of these initiatives has been the UNGPs. The UNGPs were the outcome of the appointment of John G Ruggie as the SGSR for Business and Human Rights. His appointment, and his work on the Protect Respect and Remedy ${ }^{15}$ framework saw the previous attempt to engage business and states in business and human rights dialogue, - The Norms on the responsibilities of

\footnotetext{
12 Rory Sullivan and Mary Robinson (eds). Business and Human Rights: Dilemmas and solutions (London, Routledge 2017); Robert Bird, Daniel Cahoy and Jamie Prenkert (eds) Law, Business and Human Rights: Bridging the Gap (Edward Elgar Publishing 2014)

13 Jesner v Arab Bank plc 584 U.S.(2018); Akpan v Royal Dutch Shell Arrondissementsrechtbank Den Haag, 30 January 2013 Case No C/09/337050/HA ZA 09-1580; Choc v Hudbay Materials Inc [2013] ONSC 1414; Chandler v Cape plc [2012] EWCA Civ 525; Thompson v The Renwick Group plc (2014) EWCA Civ 635; AAA \& Ors v Unilever plc \& Ors [2017] EWHC 371 (QB); Lungowe \& Ors v Vedanta Resources plc \& Konkola Copper Mines plc [2018] WLR 3575, [2017] WLR(D) 741, [2017] EWCA Civ 1528, [2018] 1 WLR 3575; Okpabi v Royal Dutch Shell plc \& Anothr [2018] EWCA Civ 191

${ }^{14}$ For a comprehensive overview of Remedy in international human rights law see, Dinah Shelton, Remedies in international human rights law, (USA, Oxford University Press 2015)

15 John G. Ruggie, 'Protect, respect and remedy: A framework for business and human rights." (2008)

3(2) Innovations: Technology, Governance, Globalisation 189-212; John G Ruggie, "Business and Human rights: Towards operationalizing the 'protect, respect and remedy' framework" UN Document A/HRC/11/13 22 (2009); Larry Cata Backer, On the Evolution of the United Nations Protect-RespectRemedy Project: the state, the corporation and human rights in a global governance context' (2011) 3 Santa Clara Journal of International Law 37
} 
transnational corporations and other business enterprises with regard to human rights - effectively abandoned. ${ }^{16}$ Although this has led to criticism regarding the use of language within, the UNGPs have nevertheless made a substantial contribution to the discourse. ${ }^{17}$

\section{The OECD Guidelines for Multinational Enterprises}

The OECD Guidelines are recommendations addressed by governments to corporations operating in or from adhering countries. Although voluntary and nonbinding, they have a unique implementation mechanism known as National Contact Points (NCPs) which provide a mediation and conciliation platform for resolving and issues that might arise. ${ }^{18}$ The Guidelines ascertain that the NCPs are to be established for "promotional activities, handling inquiries and for discussions with the parties concerned on all matters covered by the Guidelines so that they can contribute to the solution of problems which may arise in this connection." ${ }^{19}$ The procedural guidance informs still further. It notes that the role of the NCP is to ensure the effectiveness of the Guidelines and that they will operate in accordance with the core criteria for functional equivalence; visibility, accessibility, transparency and accountability. ${ }^{20}$

The procedural guidance also establishes how the NCP might be structured, suggesting options such as a senior government official, a government office, a cooperative body, including representatives of other government agencies. ${ }^{21}$ They set out its role in promoting the Guidelines, cooperating with and responding to relevant stakeholders (including other NCPs and adhering governments). Regarding the NCP's role in the resolution of issues, it plays the part of a facilitator, offering a forum for discussion and will assist the parties' concerns to deal with any issues raised in an

\footnotetext{
${ }^{16}$ Norms on the responsibilities of transnational corporations and other business enterprises with regard to human rights, (2003) Available at http://www1. umn.edu/humanrts/business/norms-Aug2003.html [Accessed June 29, 2017]

${ }_{17}$ Ciara Hackett and Luke Moffett, "Mapping the Public-Private law divide" (2016) 12 (3) International Journal of Law in Context 312-336

${ }_{18}$ The OECD Guidelines Available at < http://mneguidelines.oecd.org/database/> [Accessed August 20, 2018]

19 The OECD Guidelines p. 30. Available at < http://mneguidelines.oecd.org/database/> [Accessed August 20, 2018]

20 The OECD Guidelines p. 33 (Procedural Guidance) Available at < http://mneguidelines.oecd.org/database/> [Accessed August 20, 2018]

21 The OECD Guidelines Available at < http://mneguidelines.oecd.org/database/> [Accessed August 20, 2018]
} 
efficient and timely matter and in accordance with applicable law. ${ }^{22}$ The NCP must make (1) an initial assessment; (2) offer assistance and resources even where this means contacting other NCPs, seeking guidance from the Investment Committee, ${ }^{23}$ or even offer and facilitate access to mediation and conciliation; (3) issue a statement where there is no agreement making recommendations where appropriate, (4) protect sensitive information, ensure confidentiality (where appropriate) even where making publicly available the results of procedures; and, (5) supporting non-adhering countries (where problems might arise) in understanding issues involved. ${ }^{24}$ Additionally, the NCP is expected to report annually to the Investment Committee and this report should contain information on the activities of the NCP, including their implementation strategies. ${ }^{25}$

The Guidelines accord certain flexibility to governments regarding the structure and organisation of the NCP. However, to try and ensure some level of conformity and consistency, the OECD Guidelines outline four core criteria for functional equivalence as noted above. This means that the NCPs should function in a visible, accessible, transparent and accountable manner. ${ }^{26}$ This is a useful guide to ensure convergence within the global NCP structure. We believe that these core criteria should inform NCP activity. Whereas this may have once been the case, we believe that in the case of Ireland (as discussed in more detail below) the NCP could recognise and engage with these core criteria more fully to shape their organisation, structure and procedure. This will be increasingly more important should the importance of domestic level access to and enforcement of remedy be enshrined in a treaty. We return to these criteria in our recommendations in section III.

\footnotetext{
22 The OECD Guidelines Available at < http://mneguidelines.oecd.org/database/> [Accessed August 20, 2018]

${ }^{23}$ The Investment Committee is charged with the role of overseeing the actions of the NCP. Given the nature of the guidelines, it is preluded from acting as a judicial, or quasi-judicial body.

${ }^{24}$ The OECD Guidelines p. 34-35 Available at < http://mneguidelines.oecd.org/database/> [Accessed August 20, 2018]

${ }^{25}$ The OECD Guidelines p. 35. Available at < http://mneguidelines.oecd.org/database/> [Accessed

August 20, 2018]

${ }^{26}$ Specifically, 'The role of the National Contact Points (NCP) is to further the effectiveness of the Guidelines. NCPs will operate in accordance with core criteria of visibility, accessibility, transparency and accountability to further the objective of functional equivalence.' (Procedural Guidance, The OECD Guidelines p. 33 Available at < http://mneguidelines.oecd.org/database/> [Accessed August 20, 2018])
} 
In terms of what motivates a complaint to the NCP, recent statistics would indicate three main areas: Employment and Industrial Relations, General Policies and Human Rights. ${ }^{27}$ Human Rights seems to have taken a very recent surge in popularity within NCP specific instances which may be due to both the UNGPs (and the additional commentary to Principle 25 as discussed below) and to the updated OECD Guidelines which, in 2011 embedded a section on Human Rights within the framework. What these statistics indicate is a number of potential phenomena, such as; the size of the economy, the number of corporations residing in the state as a host or as a home country, the quality of local infrastructure, and historical links between nation-states. For example, former colonies may have closer economic, social and cultural links to certain host countries (as previous colonisers) which may be one of the reasons why countries like the United Kingdom or the Netherlands have a comparatively high ratio of specific instances reported. ${ }^{28}$ In addition, certain countries seem to engage more proactively with the NCP framework, have a more visible and accessible mechanism for contacting the NCP, or perhaps have a more engaged, motivated civil society network within the NCP model.

Therefore the role of the NCP can be summarised as the promotion of standards, a source of information and support for relevant parties, a complaints' mechanism and, where necessary, to facilitate mediation of disputes. However, the value of the OECD Guidelines have expounded in recent years as a result of the UNGPs. Their role has been reimagined within the Guiding Principles to encompass one of the ways by which victims might access a remedy. By explicitly referencing the NCP within pillar 3 of the UNGPs, the relationship between the NCP and remedy/enforcement of remedy has been firmly cemented. This has illuminated the remedy landscape somewhat, and whereas it provides additional opportunities for victims, it also supposes recognition and a willingness by the NCPs to engage with this role bestowed upon them by the UNGPs. Post the UNGPs and the OECD Guidelines, it would appear that any valid complainant could make a complaint about any multinational corporation to any NCP; however, in practice a trend has emerged. The NCP typically addresses alleged human rights violations within their own state and/or abuses abroad of multinational

${ }^{27}$ OECD NCP Database Available at < http://mneguidelines.oecd.org/database/> [Accessed August 20, 2018]

${ }^{28}$ Steven Ratner, "Corporations and Human Rights: A theory of legal responsibility" (2001) 111(3) The Yale Law Journal 443-546 
corporations (or their subsidiaries) who are headquartered within the NCP state and/or abuses that effect valid complainants based in their state.

Whereas the OECD Guidelines laid the foundations for state and corporate engagement with the business and human rights landscape (and specifically with the enforcement mechanism of the NCP), it has been the United Nations Guiding Principles on Business and Human Rights which has more fully captured attention of states, corporations and wider civil society since their implementation in 2011.

\section{UNGPs on Business and Human Rights}

The UNGPS rest on three pillars and are considered the most comprehensive contribution to the business and human rights discourse to date. The pillars of the UNGPs underscore the commitment of states and corporations uniting to protect and respect human rights. Pillar one outlines the state duty to protect human rights, whereas pillar two unpacks the corporate responsibility to respect human rights. Where a human rights impact has occurred, the third pillar of the UNGPs articulates a right to remedy. This is outlined in principles 22-25 inclusive. Principle 22 notes that:

"Where business enterprises identify that they have caused or contributed to adverse impacts, they should provide for or cooperate in their remediation through legitimate processes." 29

Principle 25 envisages accessing remedy:

"As part of their duty to protect against business-related human rights abuse, States must take appropriate steps to ensure, through judicial, administrative, legislative or other appropriate means, that when such abuses occur within their territory and/or jurisdiction those affected have access to effective remedy."30

In saying that states must take appropriate steps to remedy, principle 25 is placing a subsidiary responsibility on the state to provide remedy, and to ensure that a remedy

\footnotetext{
${ }^{29}$ Principle 22, UNGPs, Available < https://www.ohchr.org/Documents/Publications/GuidingPrinciplesBusinessHR EN.pdf> [Accessed August 2, 2018]

30 Principle 25, UNGPs, $<<$ https://www.ohchr.org/Documents/Publications/GuidingPrinciplesBusinessHR EN.pdf> [Accessed August 2, 2018]
} 
is enforced. ${ }^{31}$ By placing a subsidiary responsibility on the state to provide for remedy and access to remedy, Principle 25 supposes that states are/will always be in a position not only to fulfill their duty to remedy but also to substitute the corporate responsibility to remedy where business has failed to do so. This makes the supposition that all states are engaging with business as equals. It ignores the reality of nation - state government relationships with corporations, especially where some states may be less developed (and have a subsequent less developed infrastructure and weaker civil society) than others. ${ }^{32}$

In setting out pillar 3, Ruggie supposes that the relevant actors understand the scope and reach of remedy and that states will be in a position to take a united and coordinated approach to enforcing remedy. It would appear that the UNGPS incorporate the language of international human rights conventions of effective remedy. The additional commentary to Principle 25 states that:

"Remedy may include apologies, restitution, rehabilitation, financial or nonfinancial compensation and punitive sanctions (whether criminal or administrative, such as fines), as well as the prevention of harm, through, for example, injunctions or guarantees of non-repetition)."33

Whereas comparisons can be made between the language of international human rights conventions and the UNGPS, disparities remain. As Hackett and Moffett note, these types of reparations, whilst more expansive than traditional private law remedies, do not reflect the entire position of remedy in international human rights law. ${ }^{34}$ They note that the remedies not referenced in the commentary (e.g. acknowledgement of responsibility) are typically those that go toward the more public

\footnotetext{
${ }^{31}$ Karlijn Kuijpers, Mariette van Huijstee, and Joseph Wilde-Ramsing. "A normative-empirical analysis of state duties and corporate responsibilities related to adverse human rights impacts on the Amazonian minerals-energy frontier" (2014) 84 Journal of Cleaner Production 786-796

32 Matthew Genasci and Sarah Pray, "'Extracting accountability: The implications of the resource curse for CSR theory and practice". [2008] 11 Yale Human Rights and Development Law Journal 37-58 - in this article Genasci and Pray use the Extractive Industries Transparency Initiative (EITI) to show that the relationship between state and business may be diluted (in some cases) to one of rent collection. This has implications for transparency, responsibility and accountability.

More generally, see Stephen Ratner, "Corporations and Human Rights: A theory of legal responsibility" (2001) 111 (3) The Yale Law Journal 443-545

${ }^{33}$ Principle 25, UNGPs, Additional Commentary Available https://www.ohchr.org/Documents/Publications/GuidingPrinciplesBusinessHR EN.pdf> [Accessed August 2, 2018] (emphasis added)

${ }^{34}$ Ciara Hackett and Luke Moffett, "Mapping the Public-Private law divide" (2016) 12 (3) International Journal of Law in Context 312-336
} 
accountability of corporations. ${ }^{35}$ Corporations could be able to agree to remedy without assuming responsibility. This in turn could lead to an accountability lacuna which could have implications for trust and legitimacy within corporate/state/community relations.

As well as outlining remedy, the additional commentary to Principle 25 also stipulates how remedies may be enforced. The commentary refers to state and non-state based judicial and non-judicial grievance mechanisms. This article is interested in the state based proposed grievance mechanism and specifically the example highlighted in the additional commentary - the National Contact Point (NCP). State-based grievance mechanisms, for example, can be administered by a branch or agency of the State, or by an independent body on a statutory or constitutional basis. Grievance mechanisms can be judicial or non-judicial. Victims can seek remedy directly or via an intermediary. Examples include (but apparently are not limited to), the courts, labour tribunals, national human rights institutions, National Contact Points under the Guidelines for Multinational Enterprises of the OECD, many ombudsperson offices and Government run complaints offices. ${ }^{36}$

This is particularly fascinating as it shows overlap between the UN and the OECD on issues pertaining to business and human rights. Perhaps of yet more interest is the fact that the UNGPs are relying (in part) on a mechanism from the OECD (the NCP) as one of the ways by which the guiding principles might be realised. This is potentially placing an obligation on an entity established under a pre-existing initiative to a different set of guidelines. Consequently, there is an expectation that the NCP extend their remit to include new initiatives. To an extent this has been realised in the language used within final reports from the NCPs. ${ }^{37}$ It anticipates engagement with the UNGPs by the NCP and indeed, that victims' experience of the NCP will be similar regardless of the country where the complaint is being made.

\footnotetext{
${ }^{35}$ Ciara Hackett and Luke Moffett, "Mapping the Public-Private law divide" (2016) 12 (3) International Journal of Law in Context 312-336. Interestingly, the wording of art. 8 of the zero draft treaty also suggests a narrow interpretation of remedy which does again challenge the capacity of remedy to act as a means of holding those that violate human rights to account.

${ }^{36}$ Principle 25, UNGPs, Additional Commentary, (emphasis added) p. 27-28 Available < https://www.ohchr.org/Documents/Publications/GuidingPrinciplesBusinessHR EN.pdf> [Accessed August 2, 2018]

${ }^{37}$ For example, Final Statement of the Irish and Netherlands National Contact Points (NCPs), p. 15 (emphasis in original) Available at < http://mneguidelines.oecd.org/database/ncp/48755060.pdf> [Accessed August 27, 2018]. The term 'responsibility to respect' is most closely linked with pillar 2 of the UNGPs and the corporate responsibility to respect human rights.
} 


\section{3. "Zero Draft" Treaty on Business and Human Rights}

In July 2018, the zero draft treaty on business and human rights was published. ${ }^{38}$ For the sake of completion, we include commentary on how this draft treaty might contribute to the international legal landscape on business and human rights. This draft indicates that, should the proposed treaty be ultimately realised (albeit with some modification), victims' right to remedy will retain (and extend) the centrality ascribed to it in the UNGPs. ${ }^{39}$ Some additional points of interest emerge:

(1) Art. 5 stipulates that jurisdiction vests in the court of the state where such acts or omissions occurred or where the alleged perpetrator is domiciled; 40

(2) Art. 8 reaffirms the right of victims to, "fair, effective and prompt access to justice and remedies". ${ }^{41}$ Although the extent of these are not discussed in this draft, they are to include - presumably as a minimum (and, in accordance with international law), “(a) restitution, compensation, rehabilitation, satisfaction and guarantees of non-repetition for victims" as well as, "(b) environmental remediation and ecological restoration." 42

\footnotetext{
${ }^{38}$ Legally binding instrument to regulate, in international human rights law, the activities of transnational corporations and other business enterprises (16.07.2018) Available at < https://www.businesshumanrights.org/sites/default/files/documents/DraftLBI.pdf> [Accessed August 27, 2018]

${ }_{39}$ Article 2, s1(b) (Purpose) Zero Draft Treaty. Available at < https://www.businesshumanrights.org/sites/default/files/documents/DraftLBI.pdf> [Accessed August 27, 2018]

The zero draft puts emphasis on the need to strengthen domestic remedies which does go some way to answering some of the criticisms of the underdeveloped third pillar of the UNGPs. For more see, John G Ruggie, Comments on the "zero draft" treaty on Business and Human Rights, (July 2018) Available at < https://www.business-humanrights.org/en/comments-on-the-"zero-draft"-treaty-onbusiness-human-rights> [Accessed August, 30 2018].

${ }^{40}$ Art. 5, Zero Draft Treaty Available at $<$ https://www.businesshumanrights.org/sites/default/files/documents/DraftLBI.pdf> [Accessed August 27, 2018]. For a timely overview, see Nilsun Gursoy, "First Draft of the proposed treaty on business and human rights: a step forward for access to justice and remedy for victims (part 1)" (31/08/2018) (Business and Human Rights in Ireland) Available at < https://businesshumanrightsireland.wordpress.com/2018/08/31/guest-post-firstdraft-of-the-proposed-treaty-on-business-human-rights-a-step-forward-for-access-to-justice-andremedy-for-victims-part-i/> [Accessed August 31, 2018]

${ }^{41}$ Art. 8, Zero Draft Treaty Available at $<$ https://www.businesshumanrights.org/sites/default/files/documents/DraftLBI.pdf> [Accessed August 27, 2018]

${ }_{42}$ Art. 8, Zero Draft Treaty. Available at $<$ https://www.businesshumanrights.org/sites/default/files/documents/DraftLBI.pdf> [Accessed August 27, 2018] Note, this description of remedy is not very wide reaching. Although the addition of (b) would seem to suggest recognition of the Sustainable Development Goals, they are even less developed than the UNGPs understanding of remedy. For more on this see, Ciara Hackett and Luke Moffett, "Mapping the PublicPrivate law divide: A hybrid approach to corporate accountability" (2016) 12(3) International Journal of Law in Context 312-336.
} 
(3) There is a requirement that states provide effective mechanisms for the enforcement of remedies. ${ }^{43}$

(4) "States shall take all necessary legislative, administrative or other action including the establishment of adequate monitoring mechanisms to ensure effective implementation of this Convention". 44

This treaty, if realised, would place a positive binding legal duty on states and corporations to engage with the business and human rights agenda. ${ }^{45}$ To that end, it would go beyond existing principles and guidelines, which, as soft law initiatives, rely on the goodwill (and reputation management) of the parties involved. ${ }^{46}$ Any treaty would ensure that victims' rights are more assuredly protected and respected and that the route to remedy would be more certain than the current landscape allows. However, the pathway to a treaty is not without challenge. ${ }^{47}$ The negotiations have failed to garner support from those countries typically defined as the Global North. The Irish Government - specifically the Minister for Foreign Affairs and Trade, Simon Coveney - citing concerns with the process, have specifically ruled out engagement with the UN intergovernmental group on the elaboration of a business and human rights treaty. ${ }^{48}$ Until there is a more comprehensive engagement with the ongoing negotiations, it is unlikely that the treaty will have meaningful success globally. Until then, the international landscape remains shaped by primarily the OECD Guidelines and the UNGPs. The influence of the OECD Guidelines and the UNGPS are

\footnotetext{
${ }^{43}$ Art. 8, (8) Zero Draft Treaty, (emphasis added) Available at < https://www.businesshumanrights.org/sites/default/files/documents/DraftLBI.pdf> [Accessed August 27, 2018]

${ }_{44}$ Art. 15 (1) Zero Draft Treaty, (emphasis added) Available at < https://www.businesshumanrights.org/sites/default/files/documents/DraftLBI.pdf> [Accessed August 27, 2018] 45 Olivier DeSchutter, "Towards a new treaty on business and human rights" (2016) 1(1) Business and Human Rights Journal 41-67; Surya Deva and David Bilchitz (eds.), Building a Treaty on Business and Human Rights: Context and Contours (Cambridge: Cambridge University Press, 2017). Interestingly, the current draft of the proposed treaty does not impose any human rights obligations on corporations although in its preamble it does reiterate the corporate duty to respect human rights as set out in pillar 2 of the UNGPs.

${ }^{46}$ Christine Mary Chinkin, "The challenge of soft law: Development and change in international law" (1989) 38 (4) International Comparative Law Quarterly 850 - 866.

${ }_{47}$ Nadia Bernaz has some insightful comments to make on this. See, Nadia Bernaz, "The draft UN treaty on business and human rights: The triumph of realism over idealism", (July 2018) Available at < https://www.business-humanrights.org/en/the-draft-un-treaty-on-business-and-human-rights-thetriumph-of-realism-over-idealism> [Accessed August 30, 2018]

48 Written Response to question from Sean Crowe TD (9th October 2018)

https://www.kildarestreet.com/wrans/?id=2018-10-

09a.118\&s=\%22business+and+human+rights\%22\#g120.r [Accessed October 17 2018]
} 
evidenced at a supranational level also. We look at the EU here as these have had the greatest impact on the Irish business and human rights landscape.

\section{B. EU Level Initiatives}

\section{EU Directive (2014/95/EU)}

The EU Directive on disclosure of non-financial and diversity information requires corporations to include non-financial statements in their annual reports from 2018 onwards. Part of the information that must be disclosed is the policies that these corporations implement in relation to respect for human rights. ${ }^{49}$ Whereas this does not expressly reference remedy, section nine notes both the UNGPs and the OECD guidelines, suggesting some overlap. ${ }^{50}$

\section{Council of Europe Recommendation CM/Rec (2016)}

This recommendation makes reference to the importance of access to remedy. Although it does not expressly identify NCPs, part four of the recommendation notes that:

"Member states should ensure the effective implementation of their obligations under Articles 6 and 13 of the European Convention on Human Rights and other international and European human rights instruments, to grant to everyone access to a court in the determination of their civil rights, as well as to everyone whose rights have been violated under these instruments, an effective remedy before a national authority including where such violation arises from business activity". ${ }^{51}$

\footnotetext{
${ }^{49}$ Art. 7. Directive 2014/95/EU of the European Parliament and of the Council of 22 October 2014 amending Directive 2013/34/EU as regards disclosure of non-financial and diversity information by certain large undertakings and groups Text with EEA relevance

${ }^{50}$ Art. 9. Directive 2014/95/EU This has been given effect in Ireland via: S.I. No. 360/2017 - European Union (Disclosure of non-financial and diversity information by certain large undertakings and groups) Regulations 2017. Available < http://www.irishstatutebook.ie/eli/2017/si/360/made/en/print $>$ [Accessed August 15, 2018].

51 S. 31 (Part IV a.) Appendix 4, Recommendation CM/Rec (2016) 3 of the Committee of Ministers to member States on human rights and business. Available at $<$ https://search.coe.int/cm/Pages/result details.aspx?Objectld=09000016805c1ad4> [Accessed August $27,2018]$
} 
The themes of remedy, access to remedy and indeed enforcement of remedy persist. With the advancing of these themes within EU directives (and their nod to the OECD Guidelines and the UNGPs), there is the sense that this is the future trajectory of the business and human rights movement. However, the zero draft hints at a remedy framework more embedded within domestic infrastructure. ${ }^{52}$ Therefore, it is important to identify how the national approach to business and human rights - and remedy in particular- has progressed. For Ireland, where limited progress to date has occurred, the most recent development has been the Irish National Action Plan (NAP). Although this has its limitations (as discussed below), the apparent commitment of the Irish government to the NAP ensures its consideration as a tool for Business and Human Rights in Ireland.

\section{The Irish National Action Plan}

The mission statement of the Irish National Action Plan on Business and Human Rights (NAP) is:

"To promote responsible business practices at home and overseas by all Irish business enterprises in line with Ireland's commitment to the promotion and protection of human rights globally and to being one of the best countries in the world in which to do business." 53

Although much anticipated, the publication of the Irish NAP was disappointing. As noted by Darcy, the focus is on promoting business and human rights rather than mandatory legal requirements. ${ }^{54}$ Whereas the promotion of standards is one of the key criteria of the OECD Guidelines, we believe that the limiting to promotional activities suggests an Ireland willing to yet again 'take the back seat' on a global

\footnotetext{
52 John G Ruggie, "Comments on the 'zero draft' treaty on Business and Human Rights," (July 2018) Available at $<$ https://www.business-humanrights.org/en/comments-on-the-"zero-draft"-treaty-onbusiness-human-rights> [Accessed August 30, 2018]

${ }^{53}$ National Action Plan on Business and Human Rights, 2017-2020 (Mission Statement) Available at < https://www.dfa.ie/media/dfa/alldfawebsitemedia/National-Plan-on-Business-and-Human-Rights-20172020.pdf> [Accessed August 27, 2018].

${ }^{54}$ Shane Darcy, "Business Trumps Human Rights? On Ireland's National Action Plan on Business and Human Rights" (19/02/2018) (Business and Human Rights in Ireland) Available < https://businesshumanrightsireland.wordpress.com/2018/02/19/business-trumps-human-rights-onirelands-national-action-plan-on-business-and-human-rights/> [Accessed August, 21 2018]
} 
issue. ${ }^{55}$ We assert that the Irish NAP panders to capital, at the expense of victims and of the business and human rights agenda more broadly speaking. We believe that the NAP has cherry-picked their business and human rights obligations - diluting these to the bare minimum. ${ }^{56}$ That said, the NAP does offer some guidance on the importance of both accessing and enforcing remedy. Section one sets out the international context that informed the development of the Irish NAP, section two summarises the current legislation and section three contains the priorities and actions to be taken. Of these, we note the following as particularly relevant:

xiii. "engage with business representative bodies to promote and strengthen mediation as a viable option when businesses and their stakeholders are engaged in disputes.

xiii. introduce a standing agenda item to explore international best practice and principles governing the development of operational level grievance mechanisms for individuals and communities who may be adversely impacted to make it possible for grievances to be addressed early and remediated directly.

xiv. Review how best to ensure remedy for potential victims overseas of human rights abuses by Irish companies, with a focus on barriers to justice, including legal, procedural or financial barriers." 57

Leaving aside the use of language such as "promoting" rather than ensuring, we believe that these points offer an opportunity to reimagine the existing NCP system. In particular, the NAP looks to enhance the prevailing NCP framework noting the need to:

\footnotetext{
${ }^{55}$ See, Ciara Hackett, Development in an era of Capital Control (Palgrave Macmillan 2017); Collings, D.G., Gunnigle, P. and Morley, M. (2005) 'Exploring the dynamics of Industrial Relations in US multinationals: Evidence from the Republic of Ireland.' Industrial Relations Journal 36(3): pp. 241 - 256; Collins, P. and Pontikakis, D. (2006) Innovation systems in the European periphery; the policy approaches of Ireland and Greece. Science and Public Policy. 33(10): pp. 757 - 769; Hackett, C. (2011) 'The grass is always greener: Reflecting on global disparity in corporate social responsibility' Commercial Law Practitioner 18 (July): pp. 151-157; Heenan, D.A. (2005) Flight Capital: The alarming exodus of America's best and brightest Davies - Black Publishing; Jacobsen, J.K. (1994) Chasing Progress in the Irish Republic - Ideology, Democracy and Dependent Development. Cambridge University Press.

56 This can be evidenced in the language of "encourage", "facilitate". It would have been reassuring to see stricter language here and perhaps some movement on issues such as Modern Slavery.

${ }^{57}$ National Action Plan on Business and Human Rights, 2017-2020 (section 3, II) Available at < https://www.dfa.ie/media/dfa/alldfawebsitemedia/National-Plan-on-Business-and-Human-Rights-20172020.pdf> [Accessed August 27, 2018].
} 
"Facilitate mediation where appropriate in the OECD National Contact Point grievance procedures for cases arising under the OECD Multinational Guidelines following the publication of national procedures to give effect to the Guidelines." 58

This brief overview serves to illustrate the value placed on access to remedy/enforcement by Guidelines, Principles and Directives spanning the international, supranational and domestic sphere. This underscores the importance of the NCP as a route to remedy for victims of a human rights violation. Therefore, it is imperative that the NCP is both effective and efficient.

\section{The Irish Experience of the National Contact Point}

In Ireland, the NCP lies within the remit of the Department of Business, Enterprise and Innovation. ${ }^{59}$ It is folded within the Bilateral Trade Unit. It is difficult to access material on the OECD guidelines beyond the bilateral group on trade and corruption. ${ }^{60}$ There is no information on the activities of the NCP, when/if they meet, minutes of meetings. Further, there is limited guidance on how to make a complaint to the NCP, the process of the NCP and the anticipated timeframe. This suggests that more can be done on increasing the visibility, accessibility and effectiveness of the work of the NCP and how interested (relevant) parties can contact it.

The Irish NCP has been invoked twice according to the OECD database on specific instances. ${ }^{61}$ It is noteworthy that this information is not available on the Irish NCP site - rather users need to access the OECD site. Again, this poses some problems for the accessibility and visibility of both the NCP and the activities of said NCP in Ireland.

\footnotetext{
${ }^{58}$ National Action Plan on Business and Human Rights, 2017-2020 Annex 1 (List of additional and ongoing actions to be carried out across government). Available at < https://www.dfa.ie/media/dfa/alldfawebsitemedia/National-Plan-on-Business-and-Human-Rights-20172020.pdf> [Accessed August 27, 2018].

Also of relevance here is the Mediation Act 2017 discussed below. This will assist in the implementation of some of the provisions of the NAP.

59 Department of Business, Enterprise and Innovation (OECD Guidelines) Available at https://dbei.gov.ie/en/What-We-Do/Trade-Investment/Bilateral-Trade/OECD-Guidelines-forMultinational-Enterprises/ [Accessed August 7, 2018]

60 Tackling Bribery and Corruption < http://www.anticorruption.ie> [Accessed August 7, 2018.]

${ }^{61}$ OECD NCP Database Available at < http://mneguidelines.oecd.org/database/> [Accessed August 20, 2018]
} 
The term "specific instance" is synonymous with complaint in the NCP parlance. ${ }^{62}$ If a relevant complainant wishes to make a complaint to the NCP, they must identify how the company in question is breaching the OECD Guidelines. ${ }^{63}$ The complaints process in the UK is set out as follows: Stage 1 (lasting three months) is the receipt of the complaint and the initial assessment; Stage 2 (lasting 6 months) is from case acceptance to conclusion of mediation (or if mediation is refused or fails, fact finding); Stage 3 (3 months) drafting or publication of the final statement. ${ }^{64}$ There is an optional fourth stage - which is to report follow up actions.

To date, the most recognised specific instance has been in relation to the Corrib Gas project. ${ }^{65}$ The content of the specific instance centred on two key issues: (1) the location of the Gas terminal and the impact on the local community and (2) the extent to which the Corrib developers sufficiently engaged in consultations on health and safety impacts with the community in planning the development of the Corrib Gas Feld. The role of the NCPs in this case was, "to create a platform for dialogue on issues, which may raise underlying questions of legal interpretation of compliance". 66 The NCPs concluded that mediation had not worked, and, that the parties were irreconcilable in relation to relocating the gas processing plant. This meant that the NCP had to issue a final statement on the proceedings. The language of this final statement was interesting in that it referenced closely the wording of the UNGPs rather than the OECD Guidelines. Of note, the report remarks that:

\footnotetext{
62 Used interchangeably throughout this piece.

63 The idea of 'breach' covers a broad range of issues including, due diligence, disclosure, human rights, employment and industrial relations, environment, bribery, consumer interests, science and technology, competition, taxation.

${ }^{64}$ Due to the lack of guidance on the Irish NCP webpages, we used the UK webpage, given the similarities between the two jurisdictions. See, Department for Business, Innovation and Skills, UK National Contact Point procedures for dealing with complaints brought under the OECD Guidelines for Multinational Enterprises (2014) Available at < https://assets.publishing.service.gov.uk/government/uploads/system/uploads/attachment data/file/2705 77/bis-14-518-procedural-guidance.pdf> [Accessed August 30 2018]. We assume that the Irish NCP does not work to the same time frame as the UK NCP, but we also make the assumption that the procedure is, in many ways, similar to the UK procedure.

${ }^{65}$ Note, the second specific instance is listed as 'in progress' and no further information is available. See, "Specific instance notified by an NGO regarding the activities of a multinational enterprise in the Palestinian Authority" (2011) Available at < http://mneguidelines.oecd.org/database/instances/ie0002.htm> [Accessed August 8, 2018] 66 "Final Statement of the Irish and Netherlands National Contact Points (NCPs) on the notification dated 21 August 2008, concerning the Corrib Gas project, pursuant to the OECD Guidelines for Multinational Enterprises", Available at < http://mneguidelines.oecd.org/database/ncp/48755060.pdf> [Accessed August 27, 2018] p. 10
} 
"Enterprises have a responsibility to respect the rights of those (groups of) people on which their activities have an impact." 67

Further, that companies are expected to "exercise due diligence in the broad sense of the concept, as set out by [UNSRSG] John Ruggie". 68

This suggests that the UNGPs have surpassed the OECD Guidelines in terms of the protection and respect of human rights. This was to be anticipated particularly with the updated OECD Guidelines (in 2011) including a section on Human Rights in recognition of the UNGPs. However, in suggesting that the UNGPs lead within the business and human rights framework, there is an opportunity to enhance the existing NCP framework in a way that benefits those seeking to make a complaint whilst still recognising the core operational themes of the entity as set out by the OECD Guidelines. Further, within the context of the zero draft, the importance of remedy still remains central. The zero treaty is facing some problems, particularly in the lack of engagement from those countries typically considered to be part of the Global North. What this means is that it is unlikely (notwithstanding a significant sea change) that the proposed treaty will become more than another set of good practice guidelines (if even). That does not mean that it is without value. In being constructed by lesserdeveloped countries, and with input from civil society, it offers an interesting opportunity to see the areas for concern within business and human rights going forward from voices not always recognised on the international stage. ${ }^{69}$ Aside from the preamble, the draft treaty does not explicitly recognise or create human rights obligations for business. The relevant aspect of the preamble states: 'Underlining that all business enterprises, regardless of their size, sector, operational context, ownership and structure shall respect human rights...' ${ }^{70}$ However, the use of the term 'shall' implicitly suggests, using Clapham's reasoning, that this line in itself does in fact

\footnotetext{
${ }^{67}$ Final Statement of the Irish and Netherlands National Contact Points (NCPs), p. 15 (emphasis in original)Available at < http://mneguidelines.oecd.org/database/ncp/48755060.pdf> [Accessed August $27,2018]$. The term 'responsibility to respect' is most closely linked with pillar 2 of the UNGPs and the corporate responsibility to respect human rights.

${ }^{68}$ Final Statement of the Irish and Netherlands National Contact Points (NCPs) pp. 15-16 Available at < http://mneguidelines.oecd.org/database/ncp/48755060.pdf> [Accessed August 27, 2018]

69 See David Bilchitz, 'The necessity for a business and human rights treaty' (2016) 1 (2) Business and Human Rights Journal 203-227, 203 (especially fn 3).

${ }^{70}$ Article 1, Preamble, Zero Draft Treaty, Available at $<$ https://www.business-

humanrights.org/sites/default/files/documents/DraftLBI.pdf> [Accessed August 27, 2018]
} 
create corporate obligations. ${ }^{71}$ The application of the treaty to those businesses that engage in transnational activities (as opposed to the proposed transnational character distinction) is disappointing in that in disadvantages victims of domestic corporate human rights abuses. Nonetheless, the draft treaty has put forward a substantial 'change in tone and character of deliberations' ${ }^{72}$ when contrasted with previous initiatives. Further, it adopts some reasonable choices (that should allow for negotiations to continue and engagement with business to happen) which can be found in both the overarching themes and the overall structure of the treaty. The overarching themes can be summarised as relating to mutual legal assistance, ${ }^{73}$ international cooperation, ${ }^{74}$ consistency with international law ${ }^{75}$ and implementation. ${ }^{76}$ Lopez does recognise that these are not necessarily dealt with to the same degree or indeed with any level of precision but notes that they are a commendable focus.

With this in mind, section III proposes a series of recommendations to enhance both the procedures and operations of the Irish NCP. These take into consideration the NAPs and the themes arising from the zero draft treaty. We structure these by referencing the OECD Guidelines and specifically their core criteria for functional equivalence. We do believe that in returning to the language of the Guidelines, and where the concept of the NCP originated, the NCP can be reinvigorated in this climate of change. We believe that in the UNGPs cherry picking the role of the NCP (in the additional commentary to Principle 25) the promise of the NCP has lost some of its potential. ${ }^{77} \mathrm{We}$ also believe that this is easily remedied by revisiting the core principles

\footnotetext{
${ }^{71}$ Andrew Clapham, Human Rights Obligations of Non-state actors (2006) Oxford University Press. See also, and more generally, Christine Mary Chinkin, "The challenge of soft law: Development and change in international law" (1989) 38 (4) International Comparative Law Quarterly 850 - 866.

${ }^{72}$ Carlos Lopez, 'Towards an international convention on business and human rights' (23 July 2018) OpinioJuris < http://opiniojuris.org/2018/07/23/towards-an-international-convention-on-business-andhuman-rights-part-i/> [Accessed October 10, 2018]

${ }^{73}$ Art 11, Zero Draft Treaty, Available at < https://www.businesshumanrights.org/sites/default/files/documents/DraftLBI.pdf> [Accessed August 27, 2018]

${ }^{74}$ Art. 12, Zero Draft Treaty, Available at $<$ https://www.businesshumanrights.org/sites/default/files/documents/DraftLBI.pdf> [Accessed August 27, 2018]

${ }^{75}$ Art. 13, Zero Draft Treaty, Available at $<$ https://www.businesshumanrights.org/sites/default/files/documents/DraftLBI.pdf> [Accessed August 27, 2018]

${ }^{76}$ Art. 15, Zero Draft Treaty, Available at < https://www.businesshumanrights.org/sites/default/files/documents/DraftLBI.pdf> [Accessed August 27, 2018]

77 The UNGPs appear to limit the role of the NCP as a state based grievance mechanism. The language of the OECD guidelines however, recognizes a more nuanced role, noting its promotional role, its role in advertising and responding to queries and to drive the national agenda on responsible business conduct within the parametres of the OECD Guidelines (and by extension the UNGPs).
} 
and requirements of the NCP in addition to embedding the UNGP aspect within NCP activities.

\section{Recommendations: Enhancing the NCP experience for victims and practitioners}

The focus on business and human rights, and the climate of treaty talks in the area offers a unique opportunity to revisit and enhance existing NCP mechanisms within Ireland. Further, the emphasis from the Irish government on business and human rights initiatives via the NAP helps facilitate contributions from academia, civil society, business, law and beyond as to how we can better our experience of remedy generally, and the enforcement role of the NCP in particular. We recognise that enhancing the NCP provisions, would require "buy in" from the OECD and also from national governments. If this treaty were to be introduced (in a similar format to the draft), requiring domestic mechanisms for access to remedy, the existing framework may provide a starting point to reimagine remedy obligations under the treaty. Unfortunately, the Irish government, and the Irish NCP have not been forthcoming in developing the business and human rights infrastructure domestically. Despite the publication of the NAP for example, the failure to implement this to date, emphasizes the apparent and ongoing unwillingness to engage beyond the bare minimum on such issues that cut across the corporate/state landscape.

To this end, we offer a series of recommendations. In setting out these recommendations we return to the core criteria for functional equivalence as contained in the OECD Guidelines. We do this to ensure that the NCP remains both grounded in its origins and intentions, but also has the flexibility to adapt to initiatives such as the UNGPs, and any role that a treaty (for example the zero draft) might envisage for the NCP. We focus on four key areas. The first three relate to the core criteria and we have added the fourth area based on the complexity of the legal landscape.
A. Visibility \& Accessibility
B. Accountability
C. Transparency
D. Training 


\section{A. Visibility and Accountability}

Here we fold two of the OECD Guidelines core criteria for functional equivalence. We believe that the themes of visibility and accessibility are closely interconnected. We recommend that the NCP develops a new website distinct from the Bilateral Trading Unit. In using language more traditionally associated with the NCP (that is, referencing the page as the Irish National Contact Point), the process becomes instantly more recognisable and accessible. Through having a designated NCP webpage (albeit via the Department of Business, Enterprise and Innovation), those who need to avail of the service can instantly see the procedure for contacting the NCP, the process of an NCP complaint and the types of outcomes that might emerge. We would recommend the UK NCP as a useful template on how the Irish NCP might be reimagined. ${ }^{78}$ This website has a clear navigation system, outlining what the OECD guidelines are, how to make a complaint, the promotion of the guidelines, the UK NCP steering board, the NCP case statements on the OECD guidelines and the contact details of the UK NCP. ${ }^{79}$ Additionally, the Dutch and Italian NCP webpages demonstrate information in a clear manner which helpfully directs traffic around the site. ${ }^{80}$

We believe that in reimagining the webpage, the Irish NCP would better embody the core criteria of visibility and accessibility. ${ }^{81}$ This creates an environment where a

\footnotetext{
78 The UK National Contact Point. Available < https://www.gov.uk/government/groups/uk-nationalcontact-point-for-the-organisation-for-economic-co-operation-and-development-guidelines> [Accessed August 27, 2018]

The handbook style explanation on the complaints process is a very useful too for ensuring that those wishing to make a complaint are clear on how to do so. We would recommend this as a model for the Irish NCP. Department for Business, Innovation and Skills, UK National Contact Point procedures for dealing with complains brought under the OECD Guidelines for Multinational Enterprises (2014) Available at $<$ https://assets.publishing.service.gov.uk/government/uploads/system/uploads/attachment data/file/2705 77/bis-14-518-procedural-guidance.pdf> [Accessed August 30, 2018].

${ }^{79}$ The UK NCP. Available < https://www.gov.uk/government/groups/uk-national-contact-point-for-theorganisation-for-economic-co-operation-and-development-guidelines> [Accessed August 27, 2018]. Further, the details of NCP Steering Board minutes are uploaded online. Note, it is unclear whether there is an Irish NCP Steering Board from the webpage.

80 Italian NCP. Available (English Version) < http://www.tuacoecdmneguidelines.org/companydetails3.asp?organisationID=22751> [Accessed August 27, 2018]; Dutch NCP. Available (English Version) < https://www.oecdguidelines.nl/ncp> [Accessed August 27, 2018]

81 Procedural Guidance I., Implementation Procedures of the OECD Guidelines For Multinational Enterprises, OECD Guidelines p. 71. Available at < http://mneguidelines.oecd.org/database/> [Accessed August 20, 2018]
} 
victim is assured of the ability of the NCP to provide them with the necessary support and expertise to investigate a specific instance claim against a corporation. We envisage that with a more outward facing webpage, the NCP would engender trust which may lead to more people seeking to engage with this particular route to remedy/enforcement.

\section{B. Accountability}

In ensuring functional equivalence in the NCP activities, the OECD guidelines reference inter alia, accountability. They note the need to put the activities of the NCPs in the public eye and reference the role of national parliaments. Annual reports and regular meetings are encouraged as are ideas of shared practice. We would welcome (and recommend) a more comprehensive and visible engagement with the dissemination process in particular. ${ }^{82}$ Whereas we recognise and applaud the move by the National Action Plan on promotion of activities and so on, ${ }^{83}$ we believe that this could be developed still further to ensure that Ireland becomes a better example of the types of engagement that can emerge with a comprehensive engagement with the Guidelines and the NCP. Ireland needs to improve their reputation regarding their engagement with the National Contact Point and with their business and human rights policies more generally. Whereas the NAP has gone part of the way to demonstrate some level of commitment to the issues, the failure to effectively implement the NAP, and the limitations of the Irish NCP as articulated throughout this piece highlight the importance of enhancing their reputation in this area. ${ }^{84}$

This accountability could be tied in with the themes of visibility and accessibility mentioned above. We believe that in comprehensive online evidence of sharing good practice (including we believe, conferences/workshops/training), the NCP could manage their reputation as a viable entity for engagement by victims of human rights impacts. Further, in sharing practice with NCPs from other jurisdictions, we believe

\footnotetext{
${ }^{82}$ Core Criteria for functional equivalence in the activities of the NCP, OECD Guidelines, p. 79 Available at < http://mneguidelines.oecd.org/database/> [Accessed August 20, 2018]

${ }_{83}$ National Action Plan on Business and Human Rights, 2017-2020. p.20 Available at < https://www.dfa.ie/media/dfa/alldfawebsitemedia/National-Plan-on-Business-and-Human-Rights-20172020.pdf> [Accessed August 27, 2018].

${ }^{84}$ Ciara Hackett, Development in an era of Capital Control (Palgrave Macmillan 2017);
} 
that the NCP experience could become more unified than is currently the case. Whereas we recognise the various cultural vagaries between different jurisdictions, we believe that there should be a minimum standard of expectation for those who need to avail of the services. Put simply, a victim should not be further disadvantaged by the state where their violation occurred, or abuses abroad of multinationals who are headquartered in the state, or those abuses that effect valid complainants based in the state. ${ }^{85}$

We believe that the infrastructures are in place in Ireland to provide a better experience for those victims who need to avail of the NCP than what currently exists. This can be achieved with simple procedural changes. For example, in more ably demonstrating the process (online) and showcasing the level of shared knowledge of what is a very complex area, the Irish NCP could align with countries typically considered to be at the forefront of NCP efficiency (such as the UK).

\section{Transparency}

In addition to shared practice with other NCPs, we would recommend a comprehensive engagement with the legal, business and civil society sectors in Ireland and beyond. Although some reference is made to this in the National Action Plan, (under the initial priorities for the implementation group) we believe that this could be still more embedded. In making use of broad consultations on issues like due diligence for example, the Irish NCP could facilitate a knowledge economy in areas that cut across a number of sectors on a global scale. We believe that this would sit apart from and beyond the Sub-Groups noted in the NAP but, at the same time, would feed into the various aspects of the relevant sub-groups. We would reinforce the importance of creating a culture of sharing, transparency, engagement and accountability as we believe these to be the embodiment of the OECD Guidelines and of the business and human rights movement more broadly.

\section{Training}

\footnotetext{
85 Ciara Hackett and Luke Moffett, "Mapping the Public-Private law divide" (2016) 12 (3) International Journal of Law in Context 312
} 
This recommendation sits apart from the core functional equivalences referenced in the OECD Guidelines but feeds into the themes of accountability and transparency in particular. We recommend regular training for members of the NCP to include as a minimum, mediation training, legal developments on international procedures, due diligence and modern slavery. We recommend that this training is facilitated by independent experts in the area drawing from the fields of law, business and civil society.

The long awaited Mediation Act 2017 will offer some additional support to both the members of the NCP and those seeking a remedy. ${ }^{86}$ It will remove some of the financial barriers of seeking a remedy for victims of a human rights impact, which is in keeping with both the National Action Plan and, to an extent, aspects of the zero draft treaty. ${ }^{87}$ Of particular relevance is $\mathrm{s.11}$, which deals with the enforcing of mediation settlements. ${ }^{88}$ This would provide some much needed reassurance to the victim and indeed emphasises the importance of accountability to victims of human rights violations. ${ }^{89}$

We would also recommend, comprehensive and regular training on international developments in the area. Business and human rights encompasses a vast array of complex laws, guidelines and principles. We believe that the NCP would benefit from a regular update on legal developments even in those areas that seem beyond the traditional remit of the NCP. Therefore, we would include domestic practice in other jurisdictions here e.g. the extraterritoriality clause of the Modern Slavery Act (UK)..$^{90}$ At a case level, recent developments in the US on Alien Torts Claims for example although not having direct reference to the NCP system - does reference the right to

\footnotetext{
${ }^{86}$ Mediation Act 2017, Available at http://www.irishstatutebook.ie/eli/2017/act/27/enacted/en/html ${ }^{87} \mathrm{xv}$, II, National Action Plan; the draft treaty points to the waiving of costs where there is a financial burden on the complainant - there is no reference to this in the National Action Plan and this may be considered one of the more far reaching suggestions of the Treaty. National Action Plan Available at < https://www.dfa.ie/media/dfa/alldfawebsitemedia/National-Plan-on-Business-and-Human-Rights-20172020.pdf> [Accessed August 27, 2018].

${ }^{88}$ s. 11. Mediation Act 2017

${ }^{89}$ Ciara Hackett and Luke Moffett, "Mapping the Public-Private law divide" (2016) 12 (3) International Journal of Law in Context 312

${ }_{90}$ Modern Slavery Act 2015 (UK) < http://www.legislation.gov.uk/ukpga/2015/30/contents/enacted> See also the miscellaneous provisions outlined in Title XV, Wall Street Reform and Consumer Protection Act (2010) (Dodd Frank Act)
} 
remedy in the case of alleged complicit behaviour by a corporation. ${ }^{91}$ This example is particularly of interest in that the area of corporate complicity remains undeveloped within the business and human rights framework including the zero draft. ${ }^{92}$ It is important that the NCP is kept abreast of these developments as they arise so that they are confident in traversing the wealth of information that may form part of a specific instance report in the future.

The concept of due diligence is one which weaves through inter alia the UNGPS, the report of the Irish NCP on the Corrib gas dispute, the Irish NAP and the new zero treaty. However, there is a lack of consistency as to the meaning and reach of due diligence. Principle 15 outlines the due diligence requirements of the UNGPS as a, "process to identify, prevent, mitigate and account for how [corporations] address their impacts on human rights." 93 Interestingly however, is the perception of due diligence that Lopez advances. For him, the term evokes a legal standard, but within the UNGPs, it leans towards a series of good practices without clear legal implications. ${ }^{94}$ The zero draft describes due diligence as a standard - requiring business to prevent harm. This is, as noted by Ruggie, a "tall order." 95 We observe that the NAP proposes to develop a practical tool kit to assist in human rights due diligence. We would strongly advise that this toolkit positions the Irish definition on due diligence. In the

\footnotetext{
${ }^{91}$ As related to Alien Tort Statute (1789) 28 U.S.C. § 135 - see, Jesner v Arab Bank plc 584 U.S. (2018) (More generally and beyond the US, Akpan v Royal Dutch Shell Arrondissementsrechtbank Den Haag, 30 January 2013 Case No C/09/337050/HA ZA 09-1580; Choc v Hudbay Materials Inc [2013] ONSC 1414; Chandler v Cape plc [2012] EWCA Civ 525; Thompson v The Renwick Group plc (2014) EWCA Civ 635; AAA \& Ors v Unilever plc \& Ors [2017] EWHC 371 (QB); Lungowe \& Ors v Vedanta Resources plc \& Konkola Copper Mines plc [2018] WLR 3575, [2017] WLR(D) 741, [2017] EWCA Civ 1528, [2018] 1 WLR 3575; Okpabi v Royal Dutch Shell plc \& Anothr [2018] EWCA Civ 191) ${ }_{92}$ Nadia Bernaz, "The draft UN treaty on business and human rights: The triumph of realism over idealism", (July 2018) Available at < https://www.business-humanrights.org/en/the-draft-un-treaty-onbusiness-and-human-rights-the-triumph-of-realism-over-idealism> [Accessed August 30, 2018] ${ }_{93}$ Principle 15, UNGPs, p. 16. Available at < https://www.ohchr.org/Documents/Publications/GuidingPrinciplesBusinessHR EN.pdf> [Accessed
} August 2, 2018] Note, EU directive 2014/95/EU references the due diligence process but does not guide on what it requires via due diligence. Further, S.I. No 360/2017 does reference 'due diligence processes implemented and a description of the outcome of those policies' (regulation 5 (2) (d)) but does not, in the interpretation section guide on due diligence. For more, see, Bjorn Fasterling and Geert Demuijnck, "Human Rights in the Void? Due Diligence in the UN Guiding Principles on Business and Human Rights" (2013) 116 (4) Journal of Business Ethics 799 - 814

94 Lopez, Carlos. "The 'Ruggie Process': from legal obligations to corporate social responsibility". In Surya Deva and David Bilchitz (eds) Human Rights Obligations of Business - Beyond the corporate responsibility to respect, (Cambridge: Cambridge University Press, 2013) p. 58.

95 John G Ruggie, "Comments on the 'zero draft' treaty on Business and Human Rights", (July 2018) Available at < https://www. business-humanrights.org/en/comments-on-the-"zero-draft"-treaty-onbusiness-human-rights> [Accessed August 30, 2018] 
medium term, we would recommend that the Irish government embody the French position on this issue (which aligns more with Lopez' position). ${ }^{96}$

\section{Conclusion}

The zero draft treaty has reinforced the importance of remedying wrong within the business and human rights landscape. It will continue to face its own challenges particularly regarding cooperation from countries who do not seem to want to move beyond the existing structures in place for state protection and corporate responsibility for human rights. However, the value of the zero draft lies in how it imagines remedy, access to remedy and, to an extent - the enforcement of remedy for those who have suffered a human rights impact within existing human rights law. This is important because even at this stage, the proposed implementation and enforcement mechanism for remedy is underdeveloped in the draft. This suggests that it is (a) either not part of the terms of reference of the treaty or (b) that it is too contentious an issue to engage with (and to gain consensus on) at the current time. This means, that the role of the NCP, as defined in the OECD Guidelines, and extended by the UNGPs continues to be of integral importance for the business and human rights movement generally, and for victims seeking justice/remedy in particular.

The existing laws on business and human rights are complex and intersect international, supranational and domestic provision. Aside from the complexity of the business and human rights landscape, the interpretation, reach and role of the NCP itself is examined at various levels, and through laws and policies. This leads to some uncertainty, particularly when coupled with the subjective nature of the requirements of and for the NCP as stipulated in the OECD Guidelines. We, in providing a brief overview of the relevant law and of the Irish experience of the NCP to date, have outlined a series of suggestions which we believe will complement and extend the Irish NAP on business and human rights. Further, we believe that in enhancing the NCP profile and experience, the NCP can provide a welcoming environment for business,

\footnotetext{
${ }^{96}$ Loi no 2017 - 399 du 27 Mars 2017 relative au devoir de vigilance des sociétiés mères et des enterprises donneuses d'ordre, Available < https://www.legifrance.gouv.fr/eli/loi/2017/3/27/2017399/jo/texte> [Accessed August 12, 2018]. For an excellent overview, see Sandra Cossart, Jérôme Chaplier and Tiphanie Beau De Lomenie, The French law on duty of care: A historic step towards making globalisation work for all, (2017) 2(2) Cambridge Journal of Business and Human Rights 317323
} 
law, civil society and victims alike. In so doing, the core criteria for functional equivalence as defined by the OECD guidelines can be better realised, with the transparent and accountable NCP providing a dynamic for discourse, good practice and accessible, visible, information. 